\title{
Erratum to: Bucolic and arcadian themes in South Asia: recent works on labor, indigeneity, and productions of nature
}

\author{
Shreyas Sreenath
}

Published online: 7 December 2014

(C) Springer Science+Business Media Dordrecht 2014

\section{Erratum to: Dialect Anthropol \\ DOI 10.1007/s10624-014-9359-9}

In the original publication of the article, the first sentence of the article has been published incorrectly. The correct sentence is mentioned below:

Raymond Williams, in The Country and the City, makes a poignant remark on the resurgence of rural thematics in nineteenth century English literature (1973): "for the country-house, while it retained its emotional hold, was indeed a proper setting for an opaqueness that can be penetrated in only a single dimension: all real questions of social and personal relationship left aside except in their capacity to instigate an instrumental deciphering. In very recent times it had been leased again as a centre for criminal planning or espionage or the secret police" (p. 250).

The online version of the original article can be found under doi:10.1007/s10624-014-9359-9.

S. Sreenath $(\bowtie)$

Emory University, Lawrenceville, GA, USA

e-mail: shreyas.sreenath@emory.edu 